\title{
KARAKTERISTIK HABITAT IKAN BELIDA (Notoptera chitala)
}

\author{
Arif Wibowo") dan Mas Tri Djoko Sunarno") \\ 'Peneliti pada Balai Riset Perikanan Perairan Umum, Mariana-Palembang
}

\begin{abstract}
ABSTRAK
Ikan belida (Notoptera chilata) adalah ikan asli Indonesia yang termasuk ikan ekonomis penting atau tinggi. Ikan belida merupakan salah satu jenis ikan yang terancam kelestariannya. Ikan ini termasuk dalam kelompok ikan predator yang aktif pada malam hari, memiliki habitat di wilayah tengah khususnya rawa banjir (foad plain). Pada saat musim hujan ikan belida melakukan migrasi dari sungai utama atau bagian yang berair lainnya (anak sungai, lebung, dan lain-lain) ke rawa banjir (fload plain) untuk aktivitas pertumbuhan. Sedangkan pada musim kemarau berada di sungai utama dan daerah rawa banjiran tersebut
\end{abstract}

KATA KUNCI: habitat, ikan belida, Notoptera chitala, ekonomis penting

\section{PENDAHULUAN}

Indonesia merupakan negara kepulauan yang terletak di daerah tropis. Ditinjau dari luas wilayahnya, Indonesia merupakan salah satu negara di dunia yang memiliki wilayah terluas, sehingga kaya akan keanekaragaman flora dan faunanya, termasuk fauna ikannya. Tidak hanya perikanan laut yang memiliki beragam jenis ikan, tapi juga perikanan perairan umum (open waters) keberagaman jenisnya tinggi sebagai contoh Sungai Musi, sebagai salah satu bagian perairan umum Indonesia sudah teridentifikas 136 spesies ikan (Gaffar, 2003), belum lagi jutaan ha bagian perairan umum yang lain.

Dari berbagai spesies ikan air tawar yang menghuni perairan umum Indonesia, beberapa di antaranya termasuk ke dalam kelompok ikan asli Indonesia yang penting dan memiliki nilai ekonomis yang tinggi misalnya ikan belida (Notoptera chitala) Sebagai contoh Sumatera Selatan, ikan belida di tetapkan sebagai maskot fauna Sumatera Selatan oleh pemerintah daerah setempat, selain itu juga digunakan sebagai bahan baku untuk pembuatan makanan khas daerah seperti empek-empek, kerupuk, kemplang, dan bahan pangan yang lain. Di Propinsi Jambi ikan ini sebagai ikan unggulan daerah yang habitatnya tersebar di daerah aliran Sungai Batanghari beserta anak-anak sungainya yaitu Sungai Batang Tebo, Sungai Batang Tabir, dan Sungai Batang Tembesi.

Namun demikian, aktivitas penangkapan lebih (over fishing), penggunaan alat tangkap yang tidak ramah lingkungan, dan perubahan kondisi lingkungan perairan menyebabkan kelestarian jenis ikan ini menjadi terancam (Polinac \& Malvestuto, 1991). Hal ini, telah terjadi di Sungai Musi, Sungai Batanghari, dan Sungai Kapuas. Walaupun sering tertangkap namun populasi ikan belida cenderung mengalami penurunan. Lebih jauh, Suwejo et al. (1986), mengatakan ikan belida sudah termasuk ikan air tawar yang telah dilindungi.
Tulisan ini membahas secara singkat tentang habitat ikan belida, baik kondisi habitat untuk pertumbuhan dan makan maupun kondisi habitat untuk pemijahannya (breeding), ditambahkan juga informasi singkat tentang ikan belida. Kesemuanya ini diharapkan menjadi tambahan informasi untuk lebih memahami ikan belida, dalam upaya untuk menyelamatkan ikan belida dari kepunahan.

\section{SEKILAS TENTANG IKAN BELIDA DAN HABITATNYA}

Ikan belida di Indonesia menghuni perairan Jawa, Sumatera, dan Kalimantan. Masyarakat Kalimantan Selatan dan Kalimantan Tengah menyebut ikan ini sebagai ikan pipih. Beberapa negara seperti India, Burma, Thailand, kamboja, Vietnam, dan Malaysia juga dijumpai ikan ini (Kotelat et al., 1993), lihat Gambar 1. Walaupun begitu, ukuran panjang ikan belida ternyata bervariasi di beberapa negara, di India, ikan ini mencapai panjang lebih dari $1 \mathrm{~m}$, di Thailand pada umumnya hanya mencapai ukuran 70 sampai dengan $75 \mathrm{~cm}$ dan di Indonesia dikatakan mencapai $87,5 \mathrm{~cm}$ (Weber \& Beaufort, 1913). Untuk Indonesia, hasil yang hampir sama dikatakan oleh (Adjie \& Utomo, 1994) ikan belida di perairan lubuk lampam Sumatera Selatan mencapai panjang $83 \mathrm{~cm}$.

Apabila dilihat filogeninya, menurut Smith (1945), taksonomi ikan belida sebagai berikut phylum Chordata, kelas Pisces, subkelas Telesostemi, ordo Isopondyli, famili Notoperidae, genus Notopterus, dan spesies Notopterus chitala. Selanjutnya, Weber \& Beaufort (1913), menambahkan bahwa famili Notopteridae mempunyai 3 genus yaitu Notopterus notopterus, Notoptera chitala, dan Notopterus bornensis.

Selain pengelompokkan secara taksonomi, spesies-spesies ikan air tawar juga dapat dikelompokkan berdasarkan pada habitatnya (Welcomme, 1979) yaitu kelompok ikan putih (white 


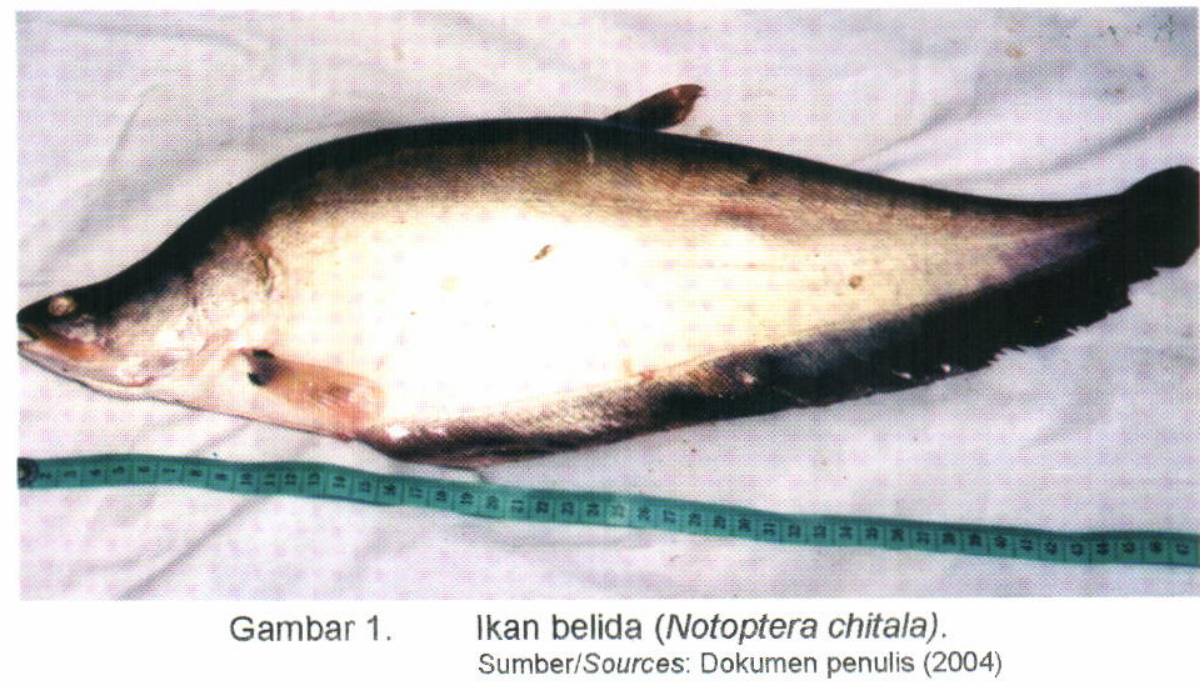

fish) dan kelompok ikan hitàm (black fish) Berdasarkan pada ikan belida termasuk dalam kelompok ikan hitam (black fish) karena memiliki habitat di perairan rawa (floodplain). Perairan rawa memiliki kualitas air yang kurang baik, khususnya kadar oksigen terlarut rendah, maka ikan dalam kelompok ini memiliki alat bantu pernapasan yang dinamakan labirin, termasuk ikan belida, sehingga dapat tinggal dan tetap bertahan di kondisi perairan rawa.

Pengertian habitat sendiri menurut Krebs (1985), adalah tempat di mana organisme (ikan) tersebut hidup. Secara keseluruhan, habitat yang ada pada daerah rawa banjiran (floodplain) menurut Welcomme (1979), dapat dipisahkan berdasarkan pada tipe substrat dasar, vegetasi tutupan, dan konsentrasi oksigen terlarut. Welcomme (1979) juga habitat utama yang ada di rawa banjiran (floodplain) berdasarkan pada musim, lihat Tabel 1.

Organisme air dapat menjalankan proses kehidupan mereka secara normal sepanjang habitat mereka sesuai dengan yang dibutuhkan. Artinya, kesesuaian habitat sangat penting. Kesesuaian habitat berkaitan erat dengan kualitas habitat dan salah satu yang menentukan kualitas habitat akuatik adalah volume air (Walks et al., 2000), sehingga ketika terjadi musim hujan, kualitas perairan rawa sedikit meningkat karena terjadi penambahan volume air. Selain itu, penambahan volume air di perairan rawa juga menyebabkan tersedianya banyak makanan dan memberikan keadaan yang baik untuk strategi reproduksi ikan (Welcomme, 1979).

Kondisi ini dimanfaatkan oleh berbagai jenis ikan tertentu untuk melakukan pemijahan, di saat yang sama ikan belida yang merupakan jenis ikan predator juga akan bermigrasi dari sungai utama ke perairan rawa mencari makan untuk kemudian melakukan pemijahan. Pada saat musim kemarau, di mana volume air surut ikan belida akan melakukan migrasi ke cekungan yang ada airnya atau sungai utama.

\section{HABITAT UNTUK PERTUMBUHAN DAN MAKAN}

Ikan belida membutuhkan kondisi lingkungan tertentu untuk pertumbuhan dan bertahan hidup. Salah satu kondisi lingkungan yang penting adalah kondisi perairan, walaupun ikan belida dapat beradaptasi pada lingkungan yang tidak terlalu baik tetapi tentu ada batasan tertentu. Tabel 2 menunjukkan sedikit gambaran tentang kondisi kualitas perairan, di mana banyak dijumpai ikan belida, yang paling tidak, merupakan habitat ikan ini.

Dari tabel dapat terlihat nilai parameter fisika dari kondisi perairan yang menunjukkan sifat reaksi sekitar netral, bersifat lunak dengan alkalinitas relatif rendah. Kondisi perairan demikian tergolong kurang subur, namun tidak berbahaya baik bagi kehidupan ikan maupun organisme air lainnya.

Salah satu daerah yang sering dijumpai ikan belida adalah lubuk lampam (berdasarkan pada hasil tangkapan nelayan) (Utomo et al., 1991). Perairan lubuk lampam adalah bagian dari aliran Sungai Lempuing yang merupakan daerah aliran Sungai Musi di Propinsi Sumatera Selatan. Perairan ini merupakan tipe perairan lebak lebung, salah satu ciri khas dari perairan lebak lebung ini adalah memiliki fluktuasi air yang sangat berbeda antara musim kemarau dan musim hujan. Pada musim penghujan air sungai naik sampai dengan meluap dan menggenangi daerah sekitarnya kecuali bagian-bagian tanah yang tinggi (talang). Sebaiknya, pada musim kemarau air sungai menjadi surut sehingga sebagian besar daerah sekitarnya kering kecuali anak-anak sungai serta tempat-tempat yang dalam tergenangi air (Arifin, 1978), kondisi air surut dapat dilihat pada Gambar 2. Sebagian besar ikan belida cenderung tinggal di perairan sungai dan sebagian lagi di tempat-tempat terdalam yang tergenang air, pada saat debit air kecil di musim kemarau, sedangkan pada saat air melimpah di musim hujan mereka menyebar ke rawa banjiran dan persawahan baik untuk memijah maupun untuk mencari makan (Adjie \& Utomo, 1994). Seperti 
Tabel 1. Habitat utama rawa banjir (floodplain) berdasarkan pada musim

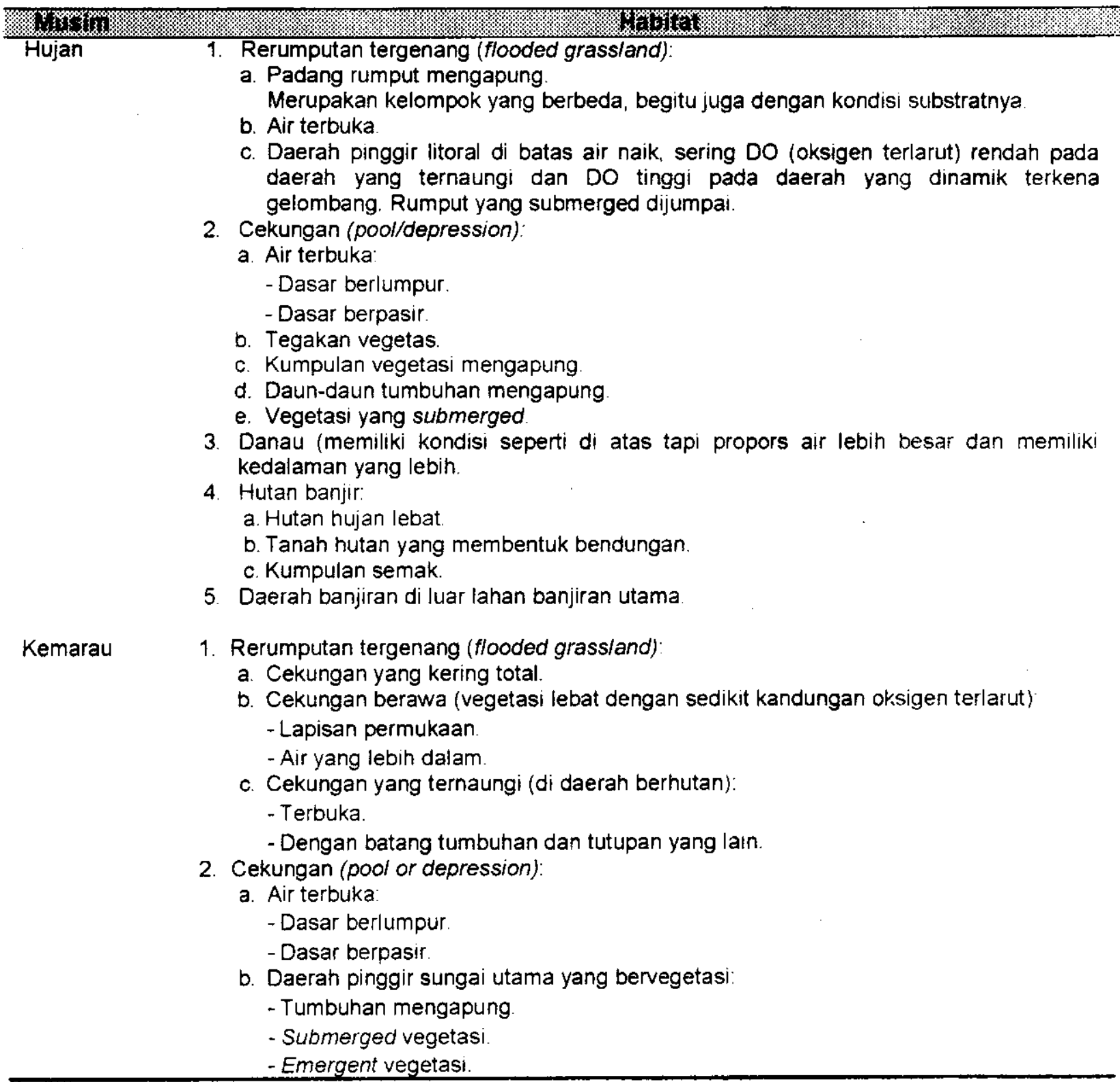

Sumber/Sources: Welcomme (1979)

halnya juga dikatakan oleh Chevey \& Lepoulain (1940) dalam Welcomme (1979), bahwa secara umum pola makan ikan yang melakukan migrasi ke rawa banjir (floodplain) di tentukan oleh musim, dalam hal ini musim hujan.

Kekayaan dan varibilitas habitat rawa banjiran (floodplain) menyediakan variasi makanan yang banyak dan berbagai tipe substrat. Makanan yang ada di rawa banjir (floodplain) berasal dari 2 sumber yaitu, dari dalam sistem itu sendiri (Autochthonous) dan dari luar sistem (Allochthonous), lihat Tabel 3. Namun, sumber yang dominan berasal dari Allochthonous yang tersimpan dalam bentuk lumpur dasar (sekitar 7\% deposit dasar cocok untuk makanan), nutrien terlarut dan produk dekomposisi (Welcomme. 1979)

Siklus makanan berhubungan dengan 2 faktor yaitu supply makanan dan kelimpahan populasi. Pada saat terjadi banjir, terjadi pertumbuhan makanan secara cepat, bersamaan dengan itu, maka ikan akan tersebar secara luas di berbagai biotipe, hal in merupakan sesuatu yang menarik bagi predator. Akibatnya akan terjadi migrasi ke perairan rawa banjir dari spesies predator setelah datang banjir. Menurut Welcomme (1979), struktur populasi ikan di tropikal dan subtropikal memiliki spesies predator yang tınggi 
Tabel 2. Keadaan kondisi fisika dan kimia perairan yang banyak ditemukan ikan belida (Notopterus chitala)

\begin{tabular}{|c|c|c|}
\hline No. & Parameter & Nilar besaran \\
\hline 1. & Suhu ${ }^{\circ} \mathrm{C}$ & $27-30$ \\
\hline 2. & Kecerahan $(\mathrm{cm})$ & $15-45$ \\
\hline 3. & Konduktivitas (umhos) & $25,3-67$ \\
\hline 4. & $\mathrm{pH}$ & $6,5-7,5$ \\
\hline 5. & Alkalinitas $\left(\mathrm{mg} \mathrm{I}^{-1} \mathrm{CaCO}_{3}\right)$ & $9,4-43$ \\
\hline 6. & Kesadahan/hardness $\left(\mathrm{mg} \mathrm{l}^{-1} \mathrm{CaCO}_{3}\right)$ & $45-156$ \\
\hline 7. & Oksigen (ppm) & $1,69-9,4$ \\
\hline 8. & $\mathrm{PO}_{2}(\mathrm{ppm})$ & $0,07-0,09$ \\
\hline 9. & Daya menggabung asam ( $\mathrm{cc} \mathrm{HCl}$ ) & $0,27-0,69$ \\
\hline 10. & Karbondioksida (ppm) & $6,95-40,66$ \\
\hline 11. & $\mathrm{NO}_{3}\left(\mathrm{mg} \mathrm{l}^{-1}\right)$ & $0,07-0,08$ \\
\hline 12. & TDS $(\mathrm{g})$ & $0,01-0,02$ \\
\hline
\end{tabular}

Sumber/Sources: Adjie et al. (1999); Adjie \& Utomo, (1994)

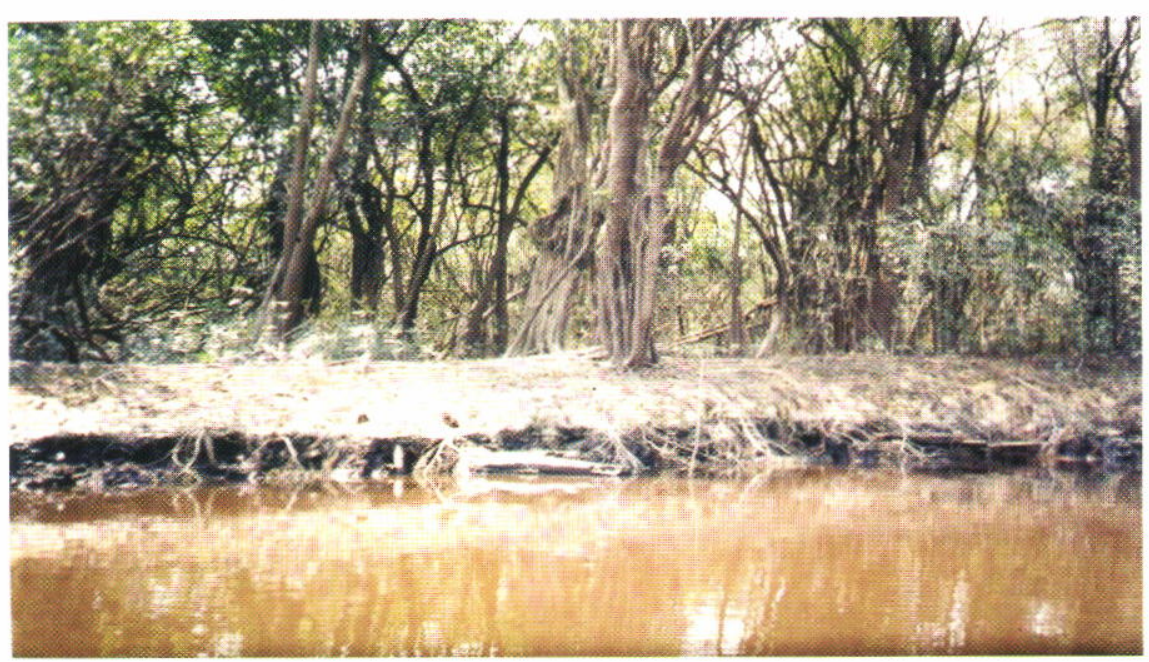

Gambar 2. Kondisi air surut di rawa banjir

Sumber/Sources: BRPPU (2003)

Tabel 3. Sumber makanan utama rawa banjiran (floodplain)

\begin{tabular}{lll}
\hline \multicolumn{1}{c}{ Sumber } & \multicolumn{1}{c}{ Kelompok } & \multicolumn{1}{c}{ Material } \\
\hline Autochthonous & Komunitas plankton & Fitoplankton \\
& Zooplankton \\
& Komunitas Bentik & Lumpur dan kumpulan mikroorganisme \\
& Serangga, cacing, dan krustacea kecil \\
& Moluska \\
& Decapoda crustacea besar \\
& Tumbuhan & Alga berfilamen, alga, makrophyt (submerged, \\
& mengapung, atau emerge) \\
& Neuston & Serangga yang hidup di permukaan, larva yang terdapat \\
& di perbatasan antara air dan udara \\
Ikan & Termasuk telur dan bentuk larvanya \\
Bahan tumbuhan & Daun, akar, bunga, buah, dan biji tumbuhan \\
Bahan hewan & Serangga termasuk semur, lalat, kumbang bersama \\
& dengan arachnida, cacing yang jatuh ke air \\
\hline
\end{tabular}


di rawa banjir (floodplain), Mago \& Leccia (1970) dalam Welcomme (1979), menambahkan lebih dari $75 \%$ populasi spesies ikan yang hidup di rawa banjir terdiri atas spesies predator khususnya pemakan ikan. Sedangkan saat air surut air menjadi terbatas sehingga konsentrasi ikan berada pada tempattempat air (lebung) dan sungai utama. Pertumbuhan produsen yang terbatas tidak sebanding dengan konsumennya, menyebabkan makanan menjadi habis. Welcomme (1979) mencatat terjadi penurunan populasi ikan pada cekungan-cekungan yang berisi air, bobot badan ikan tersebut juga menurun, secara keseluruhan terjadi penurunan bobot badan sampai dengan $10,7 \%$, namun hal ini sangat tergantung pada durasi masing-masing musim tadi. Notopterus chitala oleh Welcomme (1979) dikelompokkan ke dalam predator besar, pemakan ikan segala ukuran, udang dan kepiting. Hasil penelitian Adjie et al. (1997); (Adjie \& Utomo, 1994), memperkuat pendapat ini, lihat Tabel 4. Sifat predatornya menurut Makmur (2000) bersifat nocturnal artinya mencari makan di malam hari.

Kegiatan makan yang intensif yang dilakukan oleh ikan-ikan di rawa banjir (floodplain) membuat mereka memiliki simpanan lemak yang cukup tidak hanya untuk melewati musim kemarau sampai dengan datangnya musim hujan, tetapi juga mendorong jaringan gonad dalam persiapan untuk melakukan pemijahan pada saat terjadi banjir (musim hujan) (Welcomme, 1979).

\section{HABITAT UNTUK PEMIJAHAN}

Reproduksi sebagian besar ikan di rawa banjir (floodplain) sangat dipengaruhi oleh musim dan sebagian besar spesies menunjukkan awal musim hujan. Hal ini, berkenaan dengan strategi reproduksi, strategi reproduksi yang dilakukan oleh ikan (Welcomme, 1979) antara lain mencari tempat aman dan terlindungi untuk menaruh telur, di sana terdapat makanan maksimum dan aktivitas makan mudah dan cukup waktunya, dan terlindungi dari predator. Saat banjir jelas 2 faktor pertama terpenuhi sedangkan faktor terakhir ikan akan mengembangkan mekanisme khusus. Menurut Welcomme (1979) faktor yang memulai pematangan gonad dan mempercepat pemijahan pada umumnya tidak diketahui: ramun demikian beberapa faktor yang diduga berpengaruh antara lain perubahan fisik lingkungan seperti suhu, konduktivitas, dan aliran, ke-3 merupakan kumpulan kondisi yang menandakan banjir masuk musim hujan.

Secara alami, daerah hutan rawa merupakan tempat berkembang biak ikan belida. Ikan belida memanfaatkan hutan rawa untuk aktivitas breeding terbukti pada perairan tersebut banyak ikan yang sudah matang gonad (siap memijah) (Utomo \& Asyari, 1999).

Pemijahan diketahui terjadi pada bulan Nopember sampai dengan Pebruari setiap tahun (Makmur, 2000), bulan Nopember sampai dengan Januari (Adjie \& Utomo, 1994). Secara bertahap, induk yang sudah matang gonad berpindah beruaya menuju daerah rawa banjiran yang dikenal dengan nama flood plain, terutama hutan rawa banyak ditumbuhi tanaman dengan substrat keras, seperti pohon-pohon yang sudah mati sebagai tempat menempelkan telur (Makmur, 2000), induk ikan bellida menempelkan telur-tèlurnya pada benda-benda yang berada 1,5 sampai dengan $2 \mathrm{~m}$, di bawah permukaan air (Adjie \& Utomo, 1994). Selain itu, batang kayu baik yang hidup maupun yang sudah mati merupakan rumpon bagi ikan kecil dan udang yang merupakan makanan utama ikan ini, sehingga pada waktu melakukan pemijahan mudah mendapatkan makanan. Balon (1975) dalam Welcomme (1979), menambahkan Notoptherus chitala termasuk kelompok ikan yang membangun sarang dengan apa dan di mana, sejauh memenuhi strategi reproduksinya.

Setelah telur menetas dan berkembang biak menjadi larva, hutan rawa yang terlindungi dari kondisi alam yang ekstrem seperti angin, ombak dan gangguan lain juga berfungsi sebagai tempat asuhan. Ini karena menyediakan makanan alami plankton dan serangga air yang melimpah bagi larva atau anak belida (Makmur, 2000). Seperti juga diungkapkan oleh Adjie \& Utomo (1994) bahwa ikan belida menggunakan kayu pohon yang terendam dalam air sebagai tempat pemijahan, meletakkan telur, dan perlindungan anaknya.

Tabel 4. Komposisi dan indeks bagian terbesar makanan ikan belida (Notopterus chitala)

\begin{tabular}{|c|c|c|}
\hline 10 & 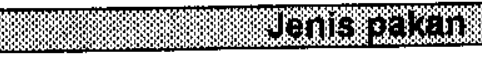 & Tha \\
\hline 1. & Ikan & $50,02-78,94$ \\
\hline 2. & Udang & $3,61-21,87$ \\
\hline 3. & Serangga & 0,09 \\
\hline 4. & Cacing & 0,01 \\
\hline 5. & Gastropoda & 0,01 \\
\hline 6. & Bahan tumbuhan & $0,62-6,99$ \\
\hline 7. & Tidak teridentifikasi & $10,36-27,49$ \\
\hline
\end{tabular}

Sumber/Sources: Adjie et al. (1999); (Adjie \& Utomo, 1994) 


\section{KESIMPULAN}

Ikan belida adalah ikan asli Indonesia yang memiliki nilai penting dan ekonomis, khususnya di Sumatera Selatan, di mana ikan ini menjadi maskot daerah dan sebagai bahan baku makanan khas daerah. Ikan ini termasuk dalam kelompok ikan predator, yang aktif pada malam hari, memiliki habitat di wilayah tengah khususnya rawa banjir (foodplain). Pada saat musim hujan ikan belida melakukan migrasi dari sungai utama atau bagian yang berair lainnya (anak sungai, lebung, dan lain-lain), ke rawa banjir (floodplain) untuk melakukan aktivitas pertumbuhan (mencari makan) dan reproduksi (memijah) sedangkan pada musim kemarau ikan belida berada pada tempat-tempat yang ada airnya, baik di sungai utama maupun di daerah rawa banjir (floodplain) tersebut.

\section{DAFTAR PUSTAKA}

Anonim. 1993. Laporan akhir studi identifikasi atau inventarisasi plasma nuftah perikanan perairan Umum. Dinas Perikanan Daerah Tingkat I Jambi. 119 hal.

Adjie, S. \& A. D. Utomo. 1994. Aspek biologi ikan belida (Notopterus chitala) di Sungai Lempuing, Sumatera Selatan. Prosiding Seminar PPEHP Perikanan Perairan Umum. Palembang. Hal: 174177.

Adjie, S., Husnah, \& A. K. Gaffar. 1999. Studi biologi ikan belida (Notoptherus chitala) di daerah aliran Sungai Batanghari, Propinsi Jambi. Jumal Penelitian Perikanan Indonesia. 5 (1). Jakarta. Hal: 38-43.

Arifin, Z. 1978. Beberapa aspek penangkapan di perairan lubuk lampam. Simposium Modern Perikanan Rakyat. Jakarta. 36 hal.

Gaffar, A. K. 2003. Upaya pelestarian dan pengembangan plasma nutfah ikan di perairan umum Sumatera Selatan. Makalah Pembekalan Pengurus Komisi Daerah Plasma Nuftah Propinsi Sumatera Selatan. Palembang. $8 \mathrm{hal}$.

Kottelat, M., J. A. Whitten, N. Kartikasari, \& S. Wiryoatmojo. 1993. Freshwater fishes of Western
Indonesia and Sulawesi. Periplus Edition and Emdi Project Indonesia. Jakarta. 221 hal.

Krebs, C. J. 1985 . Ecology. The Experimental Analysis of Distribution and Abundance. Third Edition. Harper Collins Publisher. New York. p: 8688.

Makmur, S. 2000. Ikan belida maskot Sumatera Selatan. Palembang Pos. Palembang.

Pollnac, R. B. \& S. P. Malvestuto. 1991. Biological and socio economic condition for the development of riverine fisheries resources in Kapuas and Musi River. Temu Karya Ilmiah Pengkajian Kebijakan Pengelolaan Sungai Perairan Umum bagi Perikanan. Jakarta. $231 \mathrm{p}$.

Smith. 1945. The fresh water fishes of Siam or Thailand Smithsonian. United States National Museum Bulletin Washington. USA. 57-59 p.

Suwejo, I. S. Supangkat, S., I Y Yunita. 1986 Limnologi dan konservasi lingkungan hidup pelestarian rawa, danau, dan sungai habitat biota langkat. Prosiding Ekspose Limnologi dan Pembangunan. Bogor. hal: 87-95.

Utomo, A. D. \& Asyari. 1999. Peranan ekosistem hutan rawa air tawar bagi kelestarian sumber daya perikanan di Sungai Kapuas, Kalimantan Barat. Jurnal Penelitian Perikanan Indonesia. 5 (3): 1-13.

Utomo, A. D., S. Adjie, \& Asyari. 1991. Aspek biologi ikan lais di perairan lubuk lampam Sumatera Selatan. Buletin Penelitian Penikenan Darat. 9 (2). Bogor. Hal: 1-7.

Walks, D. J., H. W. LI, \& G. H. Reeves. 2000. Trout, summer flows, and irrigation canals: A study of habitat condition and trout population within a complex system. Management and Ecology of River Fisheries. University of Hull. United Kingdom. p. $115-126$.

Weber \& De Beauford. 1913. The fishes of the Indo Australia Archipelago. Leiden. p: 10-11.

Welcomme, R. L. 1979. Fisheries ecology of floodplain river. Longman. London. $317 \mathrm{p}$. 